\title{
THE EFFECT OF USING SELF-EXPLANATION READING TRAINING (SERT) STRATEGY ON STUDENTS' READING COMPREHENSION
}

\author{
Roswati \\ State Islamic University Sultan Syarif Kasim of Riau, Indonesia \\ roswati_rm@yahoo.co.id \\ Fauzan Ahmad \\ State Islamic University Sultan Syarif Kasim of Riau, Indonesia \\ Fauzanday1023@gmail.com
}

\begin{abstract}
The aim of this study was to analyze the effect of using self-explanation reading training (sert) strategy on students' reading comprehension. This research applied a Quasi-experimental research. There were 44 students as sample from 153 students of eleventh grade at MA Darul Hikmah Pekanbaru by using cluster random sampling technique. This researcher used multiple choice test. T-test was used to analyze the data. This research used an independent t-test formula by using SPSS 16 version. Based on the analysis of T-test Formula, $\mathrm{Ha}$ is accepted because the sig. value is $0.000<0.05$. The research was conclude that there is significant difference of using Self-Explanation Reading Training (SERT) Strategy on reading comprehension in report text of the eleventh grade students at MA Darul Hikmah Pekanbaru.
\end{abstract}

Key words: Effect, Self-explanation Reading Training (SERT), Reading comprehension.

\section{Introduction}

As one of the language skills, reading is consumed by everyone especially for literate society. It is supported by Maxom, he indicates that "reading is one of the key skills in language learning" (2009:139). Dealing with the existences of reading in the world of education, Snow (2002: xiiixiv) proposes that reading will bring the readers into their cognitive capabilities such as (attention, memory, critical analytic ability, inferencing, visualization); motivation (a purpose for reading, interest in the content, selfefficacy as a reader); knowledge (vocabulary and topic knowledge, linguistic and discourse knowledge, knowledge of comprehension strategies); and experiences. By strengthening the reading skills, the students will be able to make a greater progress and development in all other areas of learning.

Based on the research of Chi and colleagues (1994) indicated that 
self-explanation can improve deep-level comprehension of text. The students were given a training of selfexplanation namely paraphrasing. It was given in three phases, introduction phase, demonstration phase and practice phase. McNamara (2004) also stated that Self-explanation is the strategy of explaining orally or in writing the meaning of written text.

This paper will discuss the concept of reading comprehension, Self-Explanation Reading Training (SERT) strategy, research method, findings, discussion, and conclusion

\section{Review of Related Literature}

\section{Reading Comprehension}

Tankersley (2013) points out that reading comprehension depends on three factors. The first factor is that the reader has command of the linguistic structures of the text. The second factor is that the reader is able to exercise metacognitive control over the content being read. It means that the reader is able to monitor and reflect on his or her own level of understanding while reading the material. The third and most important criterion influencing comprehension is that the reader has adequate background in the content and vocabulary being presented. Comprehension also consists of three elements they are; reader who is doing the comprehending, the text that is to be comprehended, and the activity in which comprehension is a part.

The reader's background knowledge and motivation are further factors in comprehension. In addition, motivation and interest influence comprehension, both directly and indirectly. Furthermore, Duffy (2009) stated that comprehension is the essence of reading because the goal of written language is communication of messages. Moreover, Scanlon states that comprehension is an active, constructive process in which the ultimate understanding of the text is determined by a combination of what is stated directly in the text and the reader's preexisting knowledge related to the topic of the text. There are five basic comprehension processes that work together simultaneously and complement one another: Microprocesses, Integrative Processes, Macroprocesses, Elaborative Processes, and Metacognitive Processes

In order to understand text, a reader must be able to identify words rapidly, know the meaning of almost all of the words and be able to combine units of meaning into a coherent message. Understanding of text results from an interaction between word identification, prior knowledge and the effective use of cognitive strategies. 8 The teacher's role during reading comprehension instruction is to ensure that students participate actively prior to reading, have the strategies and skills to use when reading, and try to make sense of the text by understanding the author's intention and bringing their own experiences to bear on the text.

When learners comprehend the reading materials, they interpret the ideas in text. It is pertaining to Blachowicz and Ogle (2008:1); reading comprehension is making sense of what is read. As a result, reading comprehension the process of the readers to construct the meaning from the text. Thus, it is clearly stated that reading is not merely recognizing the written symbols in a text but also comprehending that is getting the ideas explicitly and implicitly. Furthermore, Snow (2002:11) points out comprehension as three elements. Firstly, the reader who is doing the comprehending, secondly, the text that 
is to be comprehended, thirdly, the activity in which comprehension is a part.

\section{Teaching Reading Comprehension}

Teacher should create enjoy and fun situation in the classroom in order to make students interested in reading and they will be motivated to read. As a result, their reading skills will develop. To be successful in reading comprehension, students need to actively process what they read. That processing skill requires that students have automatic reading skills and fluency, necessary vocabulary, and textappropriate background knowledge (Wilis, 2008:127). To comprehend the text, the readers must be able to decode words, access the text integration processes in order to construct the meaning, and retain the content. Then, their brain will be stimulated by the related information. In addition, Nunan (2003:74) believes that the principles of teaching reading are as follows:

1) Exploit the reader's background knowledge

A reader background knowledge will influence the reader when comprehend the text. If students are reading on an unfamiliar topic, the teacher need to begin the reading process by building up background knowledge. It means that the students experience or what they know about the reading passage will influence them in comprehending the text.

\section{2) Build a strong vocabulary base}

Vocabulary is very important in comprehending the reading passage. The more the reader knows the meaning of the word, the easier they will catch the meaning of the text. In other words, the role of vocabulary in comprehending the text is very crucial for the readers.

\section{3) Teach for comprehension}

The teachers of reading demand their students to be able to comprehend the reading passage, but they do not teach them how to comprehend the text. Nunan (2003:75) believes that monitoring process is crucial to be successful in reading comprehension. It is related with verifying the prediction when the readers cannot obtain the meaning of the passage. It is done by the teachers, they should ensure that their students is making the correct prediction of the passage, otherwise, the teachers will help them.

4) Work on increasing reading rate

One great difficulty in the second language reading classroom is that the ability of the students read fluently. The effort of the teacher is very needed in this process. Teacher may not be impressed the students to read fast but also fluently. The teacher must work hard towards finding a balance between assisting students to improve their reading rate and develop reading comprehension skills.

\section{5) Teach reading strategies}

Strategies can be defined as a stimulation. In teaching reading comprehension, teacher must use strategies in order to stimulate students to comprehend the reading passage. Nunan (2003:76) proposes that strategies are "the tools for active, selfdirected involvement that is necessary for developing communicative ability. Strategies are not a single event, but rather a creative sequence of events that learners actively use". It means that, the use of strategies is very important in teaching reading. In order to, achieve the desired results, students need to 
learn how to use a range of reading strategies that match their purposes for reading. Teaching them how to do this should be a prime consideration in the reading classroom.

6) Encourage readers to transform strategies into skill

Nunan (2003: 77) informs the importance of distinction between strategies and skills. Strategies can be defined as conscious actions that learners take to achieve certain goals or objectives, while a skill is a strategy that has become automatic. As learners consciously learn and practice specific reading strategies, the strategies move from conscious to unconscious; from strategy to skill.

7) Build assessment and evaluation into your teaching

Every activity needs an evaluation. It is very crucial especially in the world of teaching. In teaching reading comprehension, the teacher must assess their students' reading in order to measure about the ability of a student or the quality or success of a teaching reading. Assessment may be done by test, interview, questionnaire, observation, etc.

\section{8) Strive for continuous} improvement as a reading teacher

The quality of the individual teacher is integral to success of second/foreign language readers. Reading teachers need to be passionate about their work. They should view themselves as facilitators, helping each reader discover what works best. Integrating the key principles discussed above can lead to more effective reading instruction in the second language classroom.

\section{Self-Explanation Reading Training (SERT) strategy}

According to Chi and Bassok (1989), the starting point of SERT was a technique called self-explanation. Self-explanation refers to the process of explaining the meaning of text while reading. SERT aims to improve the quality of self-explanations, and hence, to promote active reading (McNamara, 2004:2).

McNamara (2004) also developed a reading strategy intervention called Self-Explanation Reading Strategy Training (SERT) based upon the concept of selfexplanation. SERT builds upon previous self-explanation research by integrating a variety of empirically based reading strategies to scaffold students' ability to self-explain. McNamara (2004) also explained that in Self-explanation Reading Training (SERT) strategy the participants are given training that includes a description of self-explanation. In this case, the training that the researcher means is paraphrasing. After being introduced to and given example of the strategy, the participants then practice using self-explanation.

Paraphrasing is the process of restating the text in different words or in the reader's own words (McNamara, 2004). It doesn't go beyond the information in the text, so it's not an explanation of the text. In the reading strategy literature, paraphrasing is often not recognized as an effective strategy. However, it is an important part of the explanation because many readers often paraphrase the sentence to begin an explanation (McNamara, 2004; Todaro, Magliano, Millis, McNamara, \& Kurby, 2004). Paraphrases are important because they help the reader, particularly less skilled readers, to better 
understand the explicit information contained in the words and sentences of a text. Thus, paraphrasing can help the less skilled reader improve the basic understanding of the text, or text base level understanding (McNamara, O’Reilly, Best, \& Ozuru, 2006). Essentially, the act of paraphrasing externalizes the reader's understanding. This process can force the reader to fill in conceptual gaps and facilitates the activation of relevant concepts that are necessary to generate inferences (Best, Rowe, Ozuru, \& McNamara, 2005).

Syafi'i (2014) stated that a paraphrase can be defined as capturing or extracting ideas expressed by author in a short piece of writing, such as a sentence or a paragraph. Thus, the short sentence or paragraph should be expressed in your own words. In reference to this idea, Reid (1988) also gives the notion on the paraphrase as the act of extracting or capturing the author's ideas or statements to the writer's own words, but is still in the corridor of the author's ideas.

Moreover, low-knowledge participants who received SERT showed comprehension performance comparable to the high-knowledge participants. Notably, these benefits only emerged on the textbased questions. The low-knowledge readers did not have sufficient domain knowledge to generate inferences to support a coherent deep understanding of the text, or situation model. Nonetheless, the use of paraphrasing along with the generation of inferences based on logic and general knowledge helped the readers to understand the basic ideas in the text and form a more coherent textbase level understanding.

One important aspect of SERT is that it is tightly aligned with theories of comprehension and theories of knowledge and skill acquisition.
Theories of knowledge and skill acquisition prescribe that the learner benefits from the active generation of the to-be-learned information (e.g., McNamara, 1995). Hirsch (2006) argues that there are few reading strategy programs of instruction that are well aligned with theories of text comprehension. He further argues that strategy instruction has become reductionistic and isolated skill building is not well matched with the demands of reading for knowledge building. Reading strategies cannot be trained in isolation of each other or in contexts separate from the target content. Selfexplanation, in contrast, encourages the reader to use a combination of strategies, all of which are induced by the process of attempting to explain the text. Moreover, the process of explanation is a natural activity that externalizes the understanding of the text and at the same time has an overt purpose. The task is made quite simple to the reader - the reader's objective is to understand the text to the level that it can be explained. This task in and of itself clarifies the purpose of reading. This is what successful comprehenders must do to learn from text. Importantly, self-explanation is not enough. Readers must also understand how to effectively self-explain. SERT explicitly spells this out for the reader and gives examples of the various types of strategies that can be used to improve their selfexplanations. Moreover, SERT does not just give examples. The student also learns to identify the various strategies, and most importantly, practices the strategies. No skill can be learned without practice, and thus the student practices the strategies during SERT and is encouraged to practice the strategies after SERT. 


\section{Method}

This research used a quasiexperimental design: the pretest-posttest, non-equivalent group design. Thus, this research used experimental and control group. There were two variables in this research, the first variable was Self-explanation Reading Training (SERT) strategy as independent variable (x variable), reading comprehension as dependent variable (y variable). Therefore the experimental class was provided with pre-test, treatment, post-test.

The quasi-experimental design: the pretest-post-test, non-equivalent group design can be presented as follows (Cohen, 2007:283):

Table 1

The Research Design

\begin{tabular}{cccc}
\hline Class & Pre-Test & Treatment & Post-Test \\
\hline Experimental & $\mathrm{O} 1$ & $\mathrm{X}$ & $\mathrm{O} 2$ \\
Control & $\mathrm{O} 1$ & - & $\mathrm{O} 2$ \\
\hline
\end{tabular}

Where:

$\mathrm{O} 1=$ Pre-test (experimental and control class)

$\mathrm{X}=\quad$ Treatment

(Experimental class)

$\mathrm{O} 2=$ Post-test (experimental and control class)

Before the treatment, the researcher gave pre-test to all of the samples. Pre-test has given in order to find out the students' reading comprehension before implementing Self-Explanation Reading Training (SERT) strategy. Then the teacher taught reading materials continued by applying Self-Explanation Reading Training (SERT) strategy for experimental group. After six meetings, both of groups were given post-test to find out the effect of using SelfExplanation Reading Training (SERT) strategy to improve students' reading comprehension.

The population of the research was the eleventh grade students of MA Darul Hikmah Pekanbaru which is consisted of seven classes. XI IPA 1 has 22 students, XI IPA 2 has 22 students, XI IPA 3 has 23 students, XI IPS1 1 has 35 students, XI IPS 2 has 21 students,
XI AGAMA 1 has 31 students and XI AGAMA 2 has 26 students. The total number of population was 180 students.

In order to select a sample for the research, the researcher must decide the way of selecting a sample. In this case, the researcher used stratified sampling. Stratified sampling is a quantitative sampling procedure in which researcher stratify the population on same specific characteristic (e.g., gender, age, class) and randomly select the sample from population. The population above was large enough to be taken all as sample of the research. In order to minimize the expenditure of effort and time, the researcher need to reduce the population into a sample. According to Verma and Mallick (2005:202) sample is a smaller number of elements selected from a population. In this case, the researcher took two classes as the sample of this research. The sample classes were XI IPA 1 and XI IPA 2. Class XI IPA 1 was the control class, and XI IPA 2 was the experiment class. So the total number of sample was 44 students.

The researcher used test in collecting the data and the type of the test was multiple choice. The test was 
given to each group after and before giving the treatment. The test was divided into two phases:

\section{Pre-Test}

Pre-test was used to collect the data about students reading comprehension in report text before they were taught by using Selfexplanation Reading Training strategy (SERT). It was given to both experimental and control. In this test, the researcher used multiple choice type based on the indicators of reading comprehension.

\section{Post-Test}

Post-test was used to collect the data about students' reading comprehension in report text after they were taught by using Self-explanation Reading Training strategy (SERT). It was given to both experimental and control classes. In this test, the researcher also used multiple choice type based on the indicators of reading comprehension.

In order to identify the category of students' reading comprehension, the following category was used (Suharsimi, 2013: 281):

Table 2

The Classification of Students' Score

\begin{tabular}{cc}
\hline Score & Categories \\
\hline $80-100$ & Very Good \\
$66-79$ & Good \\
$56-65$ & Enough \\
$40-55$ & Less \\
$30-39$ & Fail \\
\hline
\end{tabular}

In analyzing the data, the researcher used pre-test and post-test scores of the classs. Those scores were analyzed by using statistical analysis. In this research, the researcher used $\mathrm{T}$ tests formula (independent sample ttest) and it was calculated by using software SPSS 16. Version.

The independent samples t-test was probably the single most widely used test in statistics. Pallant (2010:239) stated that independent samples t-test is used to compare the mean score of two different groups of people or conditions. It means that, it is used to determine whether or not there is significant difference at a selected groups. T-test is obtained by considering the degree of freedom $(d f)$ $=(\mathrm{N} 1+\mathrm{N} 2)-2$.
Based on the results presented, the difference obtained in two sets of scores, it did not show about the magnitude of the effect. One way to do this is that calculating the effect size statistic. According to Pallant (2010:210) effect size is a set of statistics indicating the magnitude of the differences between means in the dependent variable that is predictable from knowledge of the levels of the independent variable.

The formula is as follows:

Eta squared $=\frac{t^{2}}{t^{2}+(\mathrm{N} 1+\mathrm{N} 2)-2}$

Statistically the hypotheses are:

$$
\begin{aligned}
& \mathrm{H}_{0}=\mathrm{t}_{\mathrm{o}}<\mathrm{t}^{-}{ }_{\text {table }} \\
& \mathrm{H}_{\mathrm{a}}=\mathrm{t}_{\mathrm{o}}>\mathrm{t}_{\text {table }}
\end{aligned}
$$


$\mathrm{H}_{\mathrm{o}}$ is accepted if $\mathrm{t}_{\mathrm{o}}<\mathrm{t}$-table or there was no significant difference of students' reading comprehension taught by using Self-explanation Reading Training (SERT) Strategy between students' reading comprehension taught without using Self-explanation Reading Training (SERT) Strategy of the eleventh grade at MA Darul Hikmah Pekanbaru.

$\mathrm{H}_{\mathrm{a}}$ is accepted if $\mathrm{t}_{\mathrm{o}}>\mathrm{t}$-table or there was a significant difference of students' reading comprehension taught by using Self-explanation Reading Training (SERT) Strategy between students' reading comprehension taught without using Self-explanation Reading
Training (SERT) Strategy of the eleventh grade at MA Darul Hikmah Pekanbaru.

\section{Finding and Discussion}

The Analysis of Students' Scores on Reading Comprehension of Experimental Class and Control Class.

a. The Classification of Students' Post-test Score in Experimental Class.

The following table is the description of students' post-test scores obtained from the result of test instrument of the experimental class.

Table 3

The Classification of Students' Post-Test Score on Reading Comprehension of Experimental Class

\begin{tabular}{|c|c|c|c|c|}
\hline No. & Categories & Score & Frequency & Percentage \\
\hline 1 & Very Good & $80-100$ & 14 & $64 \%$ \\
\hline 2 & Good & $66-79$ & 8 & $36 \%$ \\
\hline 3 & Enough & $56-65$ & 0 & $0 \%$ \\
\hline 4 & Less & $40-55$ & 0 & $0 \%$ \\
\hline 5 & Fail & 30-39 & 0 & $0 \%$ \\
\hline \multicolumn{3}{|c|}{ Total } & 22 & 100 \\
\hline
\end{tabular}

Referring to table IV.12, it shows that there are 5 categories of the rubric in the post-test for experimental group. There were 14 students $(64 \%)$ were in very good category, 8 students $(36 \%)$ in good category, and no student were categorized into enough, less and fail category. Thus, the majority of the students in experimental class were classified into very good category.

The Classification of Students' Posttest Score in Control Class

The following table is the description of students' post-test scores obtained from the result of test instrument of the control class. 
Table 4

The Classification of Students' Post-Test Score on Reading Comprehension of Control Class

\begin{tabular}{ccccc}
\hline No. & Categories & Score & Frequency & Percentage \\
\hline $\mathbf{1}$ & Very Good & $80-100$ & 2 & 9 \\
$\mathbf{2}$ & Good & $66-79$ & 15 & 68 \\
$\mathbf{3}$ & Enough & $56-65$ & 3 & 14 \\
$\mathbf{4}$ & Less & $40-55$ & 2 & 9.09 \\
$\mathbf{5}$ & Fail & $30-39$ & 0 & 0 \\
& Total & & 22 & 100 \\
\hline & & & (Arikunto, 2009:245)
\end{tabular}

Referring to table IV.13, it showed that there were 2 students $(9 \%)$ were in Very Good category, 15 students $(68 \%)$ were in Good category, 3 students $(14 \%)$ were in enough category, the frequency of Less category was 2 students $(9.09 \%)$ and there is no student who is categorized into fail category. Thus, the majority of the students in control class were classified into good category
Analysis of the Difference of Using Self-explanation Reading Training (SERT) Strategy on Students' Reading Comprehension in Report Text.

The data used to present the significant difference of using Selfexplanation Reading Training (SERT) Strategy on students' reading comprehension were obtained from the post-test scores of experimental and control classes calculated by using SPSS 16.0 version.

Table 5

Group Statistics

\begin{tabular}{ccccc}
\hline Group & N & Mean & Std. & \\
\hline Post & 22 & 78.86 & 6.889 & 1.469 \\
$\quad$ Experimental & 22 & 69.32 & 7.448 & 1.588 \\
Post Control & 22 & Std. Error Mean \\
\hline
\end{tabular}

Table IV.14 shows the total number of students for each class that consisted of 22 students. The mean of experimental class was 78.86 and the mean of control class was 69.32, and the standard deviation of experimental class was
1.469, while standard deviation of control class was 1.588. The second column determines the final result of the data analysis. The table is as follow: 
Table 6

Independent Samples Test

\begin{tabular}{|c|c|c|c|c|c|c|c|c|c|}
\hline & \multicolumn{2}{|c|}{$\begin{array}{c}\text { Levene's Test } \\
\text { for Equality } \\
\text { of } \\
\text { Variances }\end{array}$} & \multicolumn{7}{|c|}{ t-test for Equality of Means } \\
\hline & \multirow[b]{2}{*}{$\mathrm{F}$} & \multirow[b]{2}{*}{ Sig. } & \multirow[b]{2}{*}{$\mathrm{t}$} & \multirow[b]{2}{*}{ df } & \multirow{2}{*}{$\begin{array}{c}\text { Sig. }(2- \\
\text { taile } \\
\text { d) }\end{array}$} & \multirow{2}{*}{$\begin{array}{l}\text { Mean } \\
\text { Differe } \\
\text { nce }\end{array}$} & \multirow{2}{*}{$\begin{array}{c}\text { Std. Error } \\
\text { Differen } \\
\text { ce }\end{array}$} & \multicolumn{2}{|c|}{$\begin{array}{c}95 \% \text { Confidence } \\
\text { Interval of the } \\
\text { Difference }\end{array}$} \\
\hline & & & & & & & & Lower & Upper \\
\hline $\begin{array}{l}\text { Score Equal } \\
\begin{array}{r}\text { variances } \\
\text { assumed }\end{array}\end{array}$ & .002 & .967 & 4.413 & 42 & .000 & 9.545 & 2.163 & 5.180 & 13.910 \\
\hline $\begin{array}{l}\text { Equal } \\
\quad \begin{array}{l}\text { variances } \\
\text { not } \\
\text { assumed }\end{array}\end{array}$ & & & 4.413 & 41.747 & .000 & 9.545 & 2.163 & 5.180 & 13.911 \\
\hline
\end{tabular}

Based on the output SPSS above, independent-sample T-Test shows Levene's Test to know the same variance.

Ho: Variance Population identical

Ha: Variance Population not identical

If Probabilities $>0.05$, Ho is accepted If Probabilities $<0.05, \mathrm{Ha}$ is accepted

From the table of independent sample test above showed that the t-test result was 4.413 , df was 42 , sig. (2tailed) was 0.000 , mean difference was 9.545, standard error was 2.163 , lower difference interval was 5.180 and upper difference interval was 13.910.

If $\boldsymbol{t}_{\boldsymbol{o}}$ (t-observation) was 4.413 compared with $\boldsymbol{t}_{\boldsymbol{t}}$ (t-table) with df 42 , the t-critic point was:

Significance $5 \%=2,01$

Significance $1 \%=2,68$

It could be seen that $t_{o}=4.413$ in significance level of $5 \%$ and $1 \%(2.01<$ 4.413> 2.68). It means that $\mathrm{H}_{\mathrm{o}}$ was rejected and $\mathrm{H}_{\mathrm{a}}$ was accepted; or there is significance difference of using Selfexplanation Reading Training (SERT) Strategy on Students' Reading Comprehension at Eleventh Grade of MA Darul Hikmah Pekanbaru.

To find out the effect size between experimental class and control class, it was calculated by using eta squared formula:

$$
\begin{aligned}
& \text { Eta Squared } \\
& \frac{\mathrm{t}^{2}}{\left.\mathrm{t}^{2}+(\mathrm{n} 1+\mathrm{n} 2)-2\right)}
\end{aligned}=
$$$$
\text { Eta Squared = }
$$$$
\frac{4.413^{2}}{4.413^{2}+(22+22)-2}
$$$$
\begin{array}{ll}
\text { Eta Squared } & =\frac{19.4745}{19.4745+42} \\
\text { Eta Squared } & =\frac{19.4745}{61.4745} \\
\text { Eta Squared } & =0.32
\end{array}
$$

Based on the result above, the magnitude of the differences in the means was very large (eta squared=.032). According to Pallant (2005: 209), the guidelines for interpreting this value are: 0.01 is small 
effect, 0.06 is moderate effect, and 0.14 is large effect. It means that the using Self-explanation Reading Training (SERT) strategy has large effect on students' reading comprehension in report text.

In conclusion, teaching reading by using Self-explanation Reading Training (SERT) strategy at the eleventh grade of MA Darul Hikmah Pekanbaru is better than without using Self-explanation Reading Training (SERT) strategy.

\section{Conclusion}

This research was conducted to find out whether there is a significant difference of using Self-explanation Reading Training (SERT) Strategy on students' reading comprehension in report text. Referring to the data analysis and data presentation explained, finally the researcher concluded as follows:

1. The mean score of students' post-test in experiment class was 78,86 ; therefore the students' reading comprehension taught by using Self-explanation Reading Training (SERT) Strategy classified into good category.

2. The mean score of students' post-test in control class was 69.32; therefore the students' therefore the students' reading comprehension taught by using Self-explanation Reading Training (SERT) Strategy is classified into good category.

3. Based on the analysis of independent sample t-test, $\boldsymbol{t}_{\boldsymbol{o}}=$ 4.413 in significance level of $5 \%$ and $1 \%(2.01<4.413>$ 2.68). It means that $\mathrm{H}_{0}$ was rejected and $\mathrm{H}_{\mathrm{a}}$ was accepted; or there is significant difference of students' reading comprehension taught by using

Self-explanation Reading Training (SERT) Strategy at eleventh grade of MA Darul Hikmah Pekanbaru.

\section{References}

Arikunto, Suharsimi. 2013. Dasardasar Evaluasi Pendidikan. $2^{\text {nd }}$ Ed. Jakarta: Bumi Aksara. 2013. Prosedur Penelitian: Suatu Pendekatan Praktik. Jakarta: Rineka Cipta.

Blachowicz, Camille L. Z and Donna Ogle. $\quad 2008 . \quad$ Reading Comprehension: Strategies for Independent Learners. $2^{\text {nd }}$ Ed. New York: The Guilford Press.

Chi, M.T.H., de Leeuw, N., Chiu, M.H., \& La Vancher, C. (1994). Eliciting self-explanations improves understanding. Cognitive Science, 18, 439-477.

Cohen, Louis, Lawrence Manion and Keith Morrison.. 2007. Research Methods in Education. $6^{\text {th }}$ Ed. Canada: Taylor \& Francis e-Library.

Elena Shohamy. 1985. Practice Handbook in Language Testing for Second Language Teacher. New York: Tel-Aviv University.

Gay, L.R and Peter Airasian. 2000. Educational Research Competencies for Analysis and Application. $6^{\text {th }}$ Ed. New Jersey: Prentice-Hall, Inc,

Gerald G. Duffy. 2009. Explaining

Reading: a Research for

Teaching Concepts, Skills, and Strategies $2^{\text {nd }}$ ed. New York: The Guilford Press.

Johnson, Andrew P. 2008. Teaching Reading and Writing: A Guidebook for Tutoring and Remediating Students. United 
States of America: Rowman and Littlefield Education.

McNamara, D.S. (2004). SERT: Selfexplanation reading training. Discourse Processes, 38, 1-30.

Nunan, David. 2003. Practical English Language Teaching: Young Learners. $1^{\text {st }}$ Ed. New York: Mcgraw-Hill Companies Inc. . 2005. Practical English Language Teaching: Young Learners. $2^{\text {nd }}$ Ed New York: Mcgraw-Hill Companies Inc.

O'Reilly, T., Best, R., \& McNamara, D.S. (2004). Self-explanation reading training: Effects for low-knowledge readers. In $\mathrm{K}$. Forbus, D. Gentner, T.

Richards, Jack C. and Richard Schmidt. 2002. Longman Dictionary of Language Teaching and Applied Linguistics. $3^{\text {rd }}$ ed New York: Pearson Education Limited. . 2010. Longman Dictionary of Language Teaching and Applied Linguistic. $4^{\text {th }}$ ed. Great Britain: Pearson Education.

Snow, Catherine. 2002. Reading for Understanding: Toward a Research and Development Program in Reading Comprehension. New York: RAND.

Syafi'i, M, S. 2011. The Effective Paragraph Development: The process of Writing for Classroom Settings. Pekanbaru: Lembaga Bimbingan Belajar Syaf Intensive. . 2013. From Paragraphs to a Research Report: A Writing of English for academic Purposes. Riau: Suska Press.

Tanskerley, Karen. 2003. Threads of Reading: Strategies for Literacy Development. Virginia: Association for Supervision and Curriculum Development (ASCD).
Wilis, Judy. 2008. Teaching the Brain to Read: Strategies for Improving Fluency, Vocabulary, and Comprehension. Virginia: Association for Supervision and Curriculum Development (ASCD) 